\title{
HUBUNGAN PENERIMAAN PAJAK DAERAH BIDANG PARIWISATA DAN JUMLAH WISATAWAN DI KABUPATEN BELITUNG
}

\author{
Eka Solid Diana ${ }^{1)}$, Dr. Devi Valeriani, S.E., M.Si ${ }^{2}$ \\ ${ }^{1)}$ Mahasiswa Fakultas Ekonomi Universitas Bangka Belitung \\ Email: soliddiana17@gmail.com \\ ${ }^{2)}$ Dosen Fakultas Ekonomi Universitas Bangka Belitung \\ Email: Deviyono92@gmail.com
}

\begin{abstract}
Sektor pariwisata Kabupaten Belitung saat ini telah menjadi salah satu sektor potensial untuk dikembangkan yang dimaksudkan untuk memperluas lapangan pekerjaan dan meningkatkan pendapatan daerah. Jumlah investasi yang masuk ke Kabupaten Belitung mengalami peningkatan hal ini terlihat dengan banyaknya pembangunan hotel-hotel berbintang, restoran serta tempat hiburan. Dengan adanya pembangun hotel-hotel berbintang, restoran dan tempat hiburan menjadi salah satu sumber Pendapatan Asli Daerah (PAD) Kabupaten Belitung yang dipungut melalui pajak bidang pariwisata yaitu dari pajak hotel, pajak restoran, pajak hiburan, pajak reklame dan pajak parkir. Penelitian ini bertujuan untuk melihat pengaruh jumlah wisatawan terhadap penerimaan pajak daerah bidang pariwisata penelitian ini menggunakan pendekatan kuantitatif dan teknik analisis data menggunakan korelasi. Hasil penelitian adalah jumlah wisatawan berpengaruh positif dan signifikan terhadap pajak hotel, pajak restoran, pajak hiburan yang berarti $\mathrm{H} 0$ di tolak dan Ha diterima, jumlah wisatawan berpengaruh negatif dan tidak signifikan terhadap pajak reklame yang berarti $\mathrm{H} 0$ diterima dan Ha di tolak.
\end{abstract}

Kata Kunci: Pajak Bidang Pariwisata dan Jumlah Wisatawan

\section{Pendahuluan}

Pariwista adalah sumber utama penggerak ekonomi di negara berkembang. Sektor pariwisata seperti ekowisata dan wisata pedesaan banyak yang dikunjungi wisatawan(Lacher dan Nepal,2010). Pengembangan sektor pariwisata menyebabkan peningkatan terhadap pendapatan daerah, selain itu sektor pariwisata dapat merangsang investasi infrasruktur baru untuk menunjang keberlangsungan pariwisata dalam suatu daerah. Untuk memperbesar Pendapatan Asli Daerah maka pemerintah perlu mengembangkan dan memfasilitasi pariwisata, agar sektor pariwisata dapat memberikan sumbangan bagi pembangunan ekonomi (Novi dan Retno,2014).

Indonesia sebagai salah satu negara maritim yang memiliki ribuan pulau memiliki bibir pantai yang melintang dari sabang sampai marauke, dengan kategori kepulauan tidak heran jika potensi pariwisata yang sangat menonjol terutama pariwisata pantai, salah satunya pulau yang memiliki potensi akan daya tarik pariwisata pantai yaitu pulau belitung. Pulau belitung merupakan pulau yang berada di dalam provinsi kepulauan Bangka Belitung.

Provinsi Kepulauan Bangka Belitung memiliki potensi di bidang pariwisata karena keindahan alamnya yang menjadi objek dan daya tarik wisata salah satunya di Kabupaten Belitung yang mengalami perkembangan di bidang pariwisata sejak penayangan film Laskar Pelangi yang memperlihatkan keindahan dan keunikan pantainya. Tentunya hal ini langsung dimanfaatkan oleh pemerintah daerah dalam membangun dan mengembangkan pariwisata di Kabupaten Belitung. Kunjungan wisatawan nusantara maupun wisatawan mancanegara yang berwisata ke Kabupaten Belitung terus meningkat dapat dilihat dari kunjungan wisatawan yang semakin meningkat dari tahun ke tahun. 
Tabel 1.1 Jumlah Wisatawan Kabupaten Belitung Tahun 2013-2017

\begin{tabular}{cccc}
\hline TA & WIS & WI & TO \\
HU & MA & SN & TA \\
N & N & US & L \\
\hline 201 & 451 & 131. & 13 \\
3 & & 091 & 1.5 \\
& & & 42 \\
201 & 3.20 & 196. & 19 \\
4 & 6 & 617 & 9.8 \\
& & & 23 \\
201 & 4.38 & 247. & 25 \\
5 & 7 & 053 & 1.4 \\
& & & 40 \\
201 & 7.11 & 285. & 29 \\
6 & 2 & 773 & 2.8 \\
& & & 85 \\
201 & 9.60 & 331. & 38 \\
7 & 3 & & 2.6 \\
& & 338 & 08 \\
\hline
\end{tabular}

Sumber: Dinas Pariwisata Kabupaten Belitung,2019

salah satu sumber Pendapatan Asli Daerah (PAD) Kabupaten Belitung yang dipungut melalui pajak bidang pariwisata yaitu dari pajak hotel, pajak restoran, pajak hiburan, pajak reklame dan pajak parkir. Pajak yang di pungut dapat meningkatkan Pendapatan Asli Daerah (PAD) guna membantu pemerintah melaksanakan program pembangunan, mensejahterakan daerah, serta pembiayaan program kerja pemerintah lainnya (Dubin,2013).

Pajak merupakan sumber utama penerimaan daerah, pajak memang miliki nilai strategis dalam hal meningkatkan kemajuan daerah, khususnya dalam hal pembangunan. Pungutan pajak dari masyarakat, keseluruhan akan dikelola oleh pemerintah yang selanjutnya akan digunakan untuk sejumlah pembiayaan pembangunan daerah. Mengingat PAD yang diperoleh dari pajak bidang pariwisata terdiri dari lima jenis pajak yaitu pajak hotel, pajak restoran, pajak hiburan, pajak reklame dan pajak parkir,maka perlu diketahui penerimaan pajak daerah bidang pariwisata yang paling besar yaitu pajak hotel sebesar Rp. 24.570.544.776 miliyar. Penelitian ini sejalan dengan penelitian yang pernah dilakukan oleh Rita Purnamasari (2013) berjudul pengaruh jumlah kunjungan wisatawan terhadap pajak hiburan, pajak hotel, pajak restoran dan pendapatan asli daerah kota bandung tahun 20052012 yang menunjukkan hasil bahwa sacara simultan variabel jumlah wisatawan berpengaruh signifikan terhadap pajak hotel, pajak restoran dan pajak hiburan.

\section{Tinjauan pustaka}

\subsection{Pajak}

Pajak adalah iuran kepada kas negara berdasarkan undang-undang (yang dapat di paksakan) dengan tidak mendapat jasa timbal (kontraprestasi) yang langsung dapat ditujukan dan yang digunakan untuk membayar pengeluaran umum (Soemitro,2013). Pajak adalah prestasi kepada pemerintah yang terutang melalui norma-norma umum, dan yang dapat dipaksakan, tanpa ada kalanya kontra prestasi yang dapat ditunjukkan dalam hal yang individual, maksudnya adalah membiayai pengeluaran pemerintah (Suandy,2010).

\subsection{Pajak Hotel}

Berdasarkan Undang-Undang Nomor 28 Tahun 2009 Pasal 1, pajak hotel adalah pajak atas pelayanan yang disediakan oleh hotel. Objek pajak hotel adalah pelayanan yang disediakan hotel dengan pembayaran. Subjek pajak hotel adalah 
orang pribadi atau badan yang melakukan pembayaran kepada orang pribadi atau badan yang mengusahakan hotel. Tarif ditetapkan paling tinggi 10\% dan ditetapkan dengan peratiran daerah kabupaten/kota yang bersangkutan.

\subsection{Pajak Restoran}

Pajak Restoran adalah pajak atas pelayanan restoran. Pada pajak restoran yang menjadi objek pajak adalah pelayanan yang disediakan restoran dengan pembayaran. Subjek pajak restoran adalah orang pribadi atau badan yang melakukan pembayaran kepada restoran. Wajib pajaknya adalah orang pribadi atau badan yang mengusahakan restoran. Dasar pengenaan pajak restoran adalah jumlah pembayaran yang dilakukan kepada restoran. Tarifnya paling tinggi $10 \%$.

\subsection{Pajak Hiburan}

Sesuai dengan Undang-Undang Nomor 28 Tahun 2009 Pasal 1, pajak hiburan adalah pajak atas penyelenggaraan hiburan. Objek pajak hiburan adalah penyelenggara hiburan dengan dipungut bayaran. Sedangkan subjek pajak hiburan adalah orang pribadi atau badan yang menonton dan atau menikmati hiburan. Wajib pajaknya adalah orang pribadi atau badan yang menyelenggarakan hiburan. Dasar pengenaan pajak hiburan adalah jumlah uang yang diterima oleh penyelenggara hiburan.

\subsection{Pajak Reklame}

Menurut undang-undang Republik Indonesia Nomor 28 Tahun 2009 pasal 1 angka 26 dan 27, pajak reklame adalah pajak atas penyelengaraann reklame. Sedangkan yang dimaksud reklame benda, alat, pembuatan,atau media yang bentuk

dan corak ragamnya dirancang untuk tujuan komersil yang digunakan untuk memeperkenalkan,menganjurkan mempromosikan atau untuk menarik perhatian umum kepada suatu barang, jasa, orang atau badan yang dapat dilihat, dibaca, didengar, dirasakan atau dinikmati oleh umum.

\subsection{Pajak Parkir}

Pajak parkir adalah pajak atas penyelenggaraan tempat parkir diluar badan jalan baik yang di sediakan berkaitan dengan pokok usaha maupun yang disediakan sebagai suatu usaha, termasuk penyediaan tempat penitipan kendaraan bermotor. Parkir adalah keadaan tidak bergerak suatu kendaraan yang bersifat tidak sementara.

\subsection{Pariwisata}

Pariwisata adalah kegiatan melakukan perjalanan dengan tujuan mendapatkan kenikmatan, mencari kepuasan, mengetahui sesuatu , memperbaiki kesehatan, menikmati olahraga atau istirahat, menunaikan tugas dan lain-lain. Definisi yang luas pariwisata adalah perjalanan dari satu tempat ke tempat lain, bersifat sementara dilakukan perorangan maupun sekelompok, sebagai usaha mencari kebahagiaan dengan lingkungan hidup dalam dimensi sosal budaya alam dan ilmu.

\subsection{Jumlah Wisatawan}

Perkembangan industri pariwisata suatu daerah sangat bergantung kepada jumlah wisatawan yang datang. Salah satu indikator untuk mengukur keberhasilan industri pariwisata yang dapat memberikan dampak kepada peemerintah daerah dan masyarakat adalah jumlah kunjungan wisatawan.Menurut UU No.10 tahun 2009 pasal 1 wisata adalah kegiatan perjalanan yang dilakukan oleh seseorang atau sekelompok orang dengan mengunjungi tempat tertentu untuk tujuan rekreasi, pengembangan pribadi atau mempelajari keunikan daya tarik wisata yang dikunjungi dalam jangka waktu sementara, Wisatawan adalah orang yang melakukan wisata. Suatu perjalanan dianggap perjalanan wisata bila memenuhi 3 persyarat yang di 
perlukan yaitu harus bersifat sementara harus bersifat sukarela (voluntary) dalam arti Tidak terjadi paksaan dan tidak bekerja yang sifatnya menghasilkan upah ataupun bayaran.

\section{Metode Penelitian}

3.1 Jenis Penelitian

Jenis penelitian yang dilakukan dalam penelitian ini menggunakan data kuantitatif. Data kuantitatif adalah data yang bersifat numerik atau angka yang

\subsection{Jenis Data} dapat dianalisis dengan menggunakan statistik (Sugiyono,2014).

Jenis data dalam penelitian ini adalah data kuantitatif yaitu jenis data yang dapat diukur atau dihitung secara langsung sebagai variabel angka atau bilangan.

\subsection{Sumber data}

Data yang digunakan dalam penelitian ini menggunakan data sekunder yaitu data yang diperoleh dari Dinas Pariwisata Kabupaten Belitung data penerimaan pajak bidang pariwisata dan jumlah wisatawan.

\subsection{Teknik Analisis Data}

Penelitian ini menggunakan teknik analisis korelasi yang digunakan untuk mengukur hubungan antara dua variabel secara linier dan untuk mengatahui arah hubungan yang terjadi. jika hubungan dua variabel atau lebih dinyatakan positif, maka bila nilai satu variabel ditingkatkan, akan meningkatkan variabel yang lain, dan sebaliknya. Jika hubungan dua variabel atau lebih dinyatakan negatif, dan juga sebaliknya. Data yang digunakan berskala interval atau rasio(Duwi pryatno,2016).

\subsection{Kerangka Berpikir}

Kerangka berpikir adalah model konseptual tentang bagaimana teori berhubungan dengan berbagai faktor yang telah didefinisikan sebagai masalah yang penting (Uma Sekaran,2017).

Gambar 3.1 Kerangka Berpikir

\begin{tabular}{c|c|c|c|}
\hline Berdasa & $\begin{array}{c}\text { Pajak daerah bidang } \\
\text { pariwisata }\end{array}$ & Jumlah wisatawan \\
ahwa pajak da凡
\end{tabular} hubungan terhadap jumlah wisatawan dan sebaliknya jumlah wisatawan berpengaruh terhadap pajak daerah bidang pariwisata.

\section{Hasil dan Pembahasan}

Tabel 4.1 Hasil Korelasi Jumlah Wisatawan Terhadap Pajak Hotel Correlations

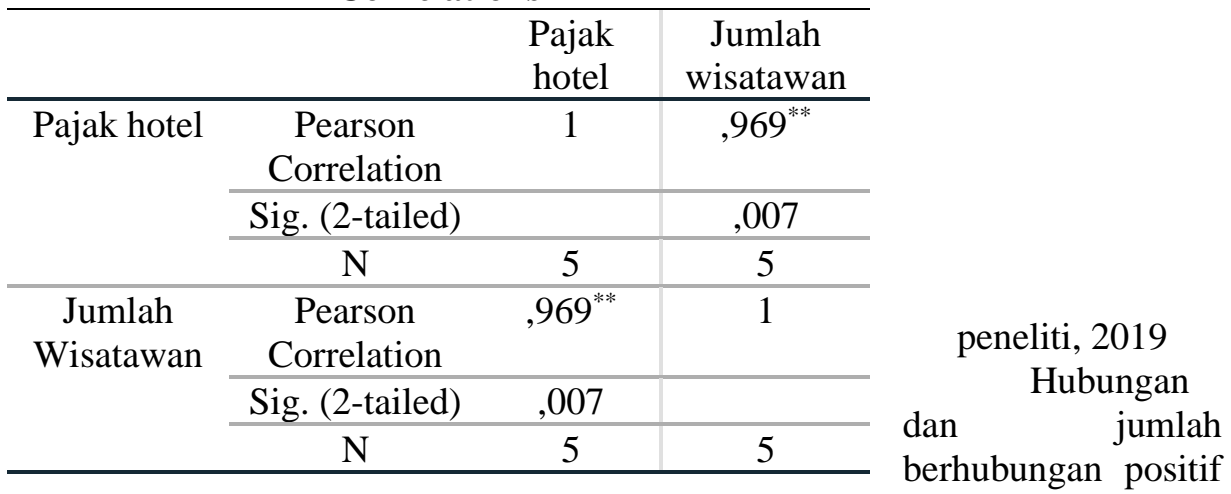

wisatawan sebesar 0,97 berarti keeratan hubungan antara pajak hotel dengan jumlah wisatawan hubungannya sangat kuat, berdasarkan hasil uji signifikan antara pajak hotel dan jumlah wisatawan memiliki hubungan yang signifikan karena $0,007<0,05$. Jadi $\mathrm{H} 0$ di tolak dan $\mathrm{Ha}$ diterima. 


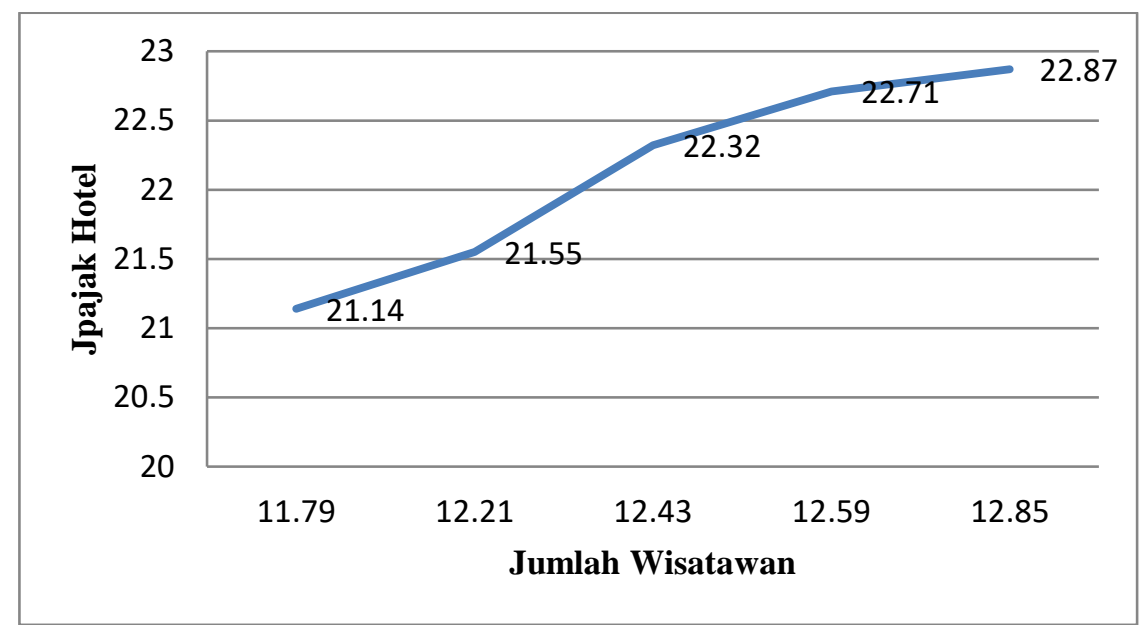

Sumber: diolah oleh peneliti,2019

\section{Gambar 4.1 Garis Linear Jumlah Wisatawan Dengan Pajak Hotel}

Berdasarkan grafik linear pada gambar 4.1 korelasi antara pajak hotel dengan jumlah wisatawan bernilai positif yang berarti terjadi hubungan yang positif, artinya jumlah wisatawan meningkat maka penerimaan pajak hotel juga meningkat dan sebaliknya jika jumlah wisatawan menurun maka penerimaan pajak hotel juga akan menurun.

Tabel 4.2 Hasil Korelasi Jumlah Wisatawan Terhadap Pajak Restoran

\begin{tabular}{cccc}
\hline \multicolumn{3}{c}{ Correlations } \\
\hline & \multicolumn{1}{c}{$\begin{array}{c}\text { Pajak } \\
\text { restoran }\end{array}$} & $\begin{array}{c}\text { Jumlah } \\
\text { wisatawa } \\
\text { n }\end{array}$ \\
\hline $\begin{array}{c}\text { Pajak } \\
\text { restoran }\end{array}$ & $\begin{array}{c}\text { Pearson } \\
\text { Correlation }\end{array}$ & 1 &, $986^{* *}$ \\
\cline { 2 - 4 } & Sig. (2-tailed) & &, 002 \\
\cline { 2 - 4 } Jumlah & $\mathrm{N}$ & 5 & 5 \\
\hline wisatawan & $\begin{array}{c}\text { Pearson } \\
\text { Correlation }\end{array}$ &, $986^{* *}$ & 1 \\
\cline { 2 - 4 } & Sig. (2-tailed) &, 002 & \\
\cline { 2 - 4 } & $\mathrm{N}$ & 5 & 5 \\
\hline
\end{tabular}

Sumber: diolah oleh peneliti,2019

Hubungan pajak restoran dan jumlah wisatawan berhubungan positif sebesar 0,99 berarti keeratan hubungan antara pajak restoran dengan jumlah wisatawan hubungannya sangat kuat, berdasarkan hasil uji signifikan antara pajak restoran dan jumlah wisatawan memiliki hubungan yang signifikan karena $0,002<0,05$. Jadi H0 di tolak dan Ha diterima. 


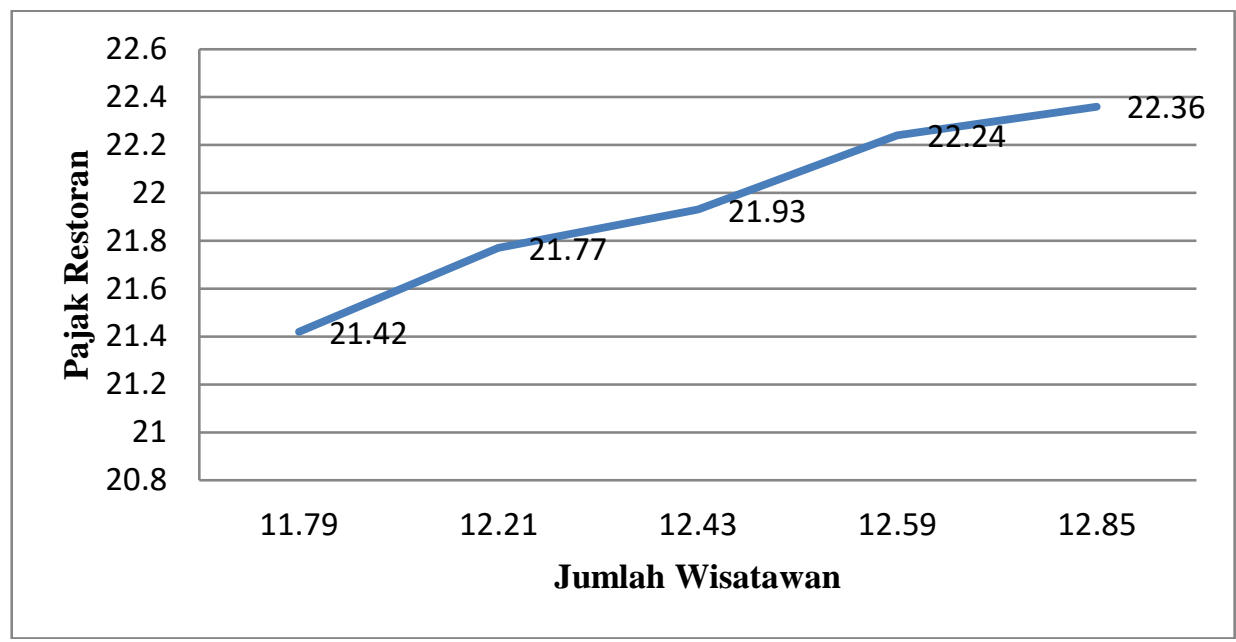

Sumber: diolah oleh peneliti,2019

\section{Gambar 4.2 Garis Linear Jumlah Wisatawan Dengan Pajak Restoran}

Berdasarkan grafik linear pada gambar 4.2 korelasi antara jumlah wisatawan dengan penerimaan pajak restoran bernilai positif berarti terjadi hubungan positif, artinya jika jumlah wistawan meningkat maka penerimaan pajak restoran juga meningkat dan sebaliknya jika jumlah wisatawan menurun maka penerimaan pajak restoran juga akan menurun.

Tabel 4.3 Hasil Korelasi Jumlah Wisatawan Dengan Pajak Hiburan

\section{Correlations}

\begin{tabular}{ccc|c}
\hline & \multicolumn{1}{c}{$\begin{array}{c}\text { Pajak } \\
\text { hiburan }\end{array}$} & $\begin{array}{c}\text { Jumlah } \\
\text { wisatawan }\end{array}$ \\
\hline \multirow{2}{*}{$\begin{array}{c}\text { Pajak } \\
\text { hiburan }\end{array}$} & $\begin{array}{c}\text { Pearson } \\
\text { Correlation }\end{array}$ & 1 &, $988^{* *}$ \\
& Sig. (2-tailed) & &, 001 \\
\cline { 2 - 4 } & $\mathrm{N}$ & 5 & 5 \\
\hline \multirow{2}{*}{$\begin{array}{c}\text { Jumlah } \\
\text { wisatawan }\end{array}$} & $\begin{array}{c}\text { Pearson } \\
\text { Correlation }\end{array}$ &, $988^{* *}$ & 1 \\
\cline { 2 - 4 } & Sig. (2-tailed) &, 001 & \\
\cline { 2 - 4 } & $\mathrm{N}$ & 5 & 5 \\
\hline
\end{tabular}

Sumber: diolah oleh peneliti,2019

Hubungan pajak hiburan dan jumlah wisatawan berhubungan positif sebesar 0,99 berarti keeratan hubungan antara pajak hiburan dengan jumlah wisatawan hubungannya sangat kuat berdasarkan hasil uji signifikan antara pajak hiburan dan jumlah wisatawan memiliki hubungan yang signifikan karena $0,001<0,05$. Jadi $\mathrm{H} 0$ di tolak dan Ha diterima.

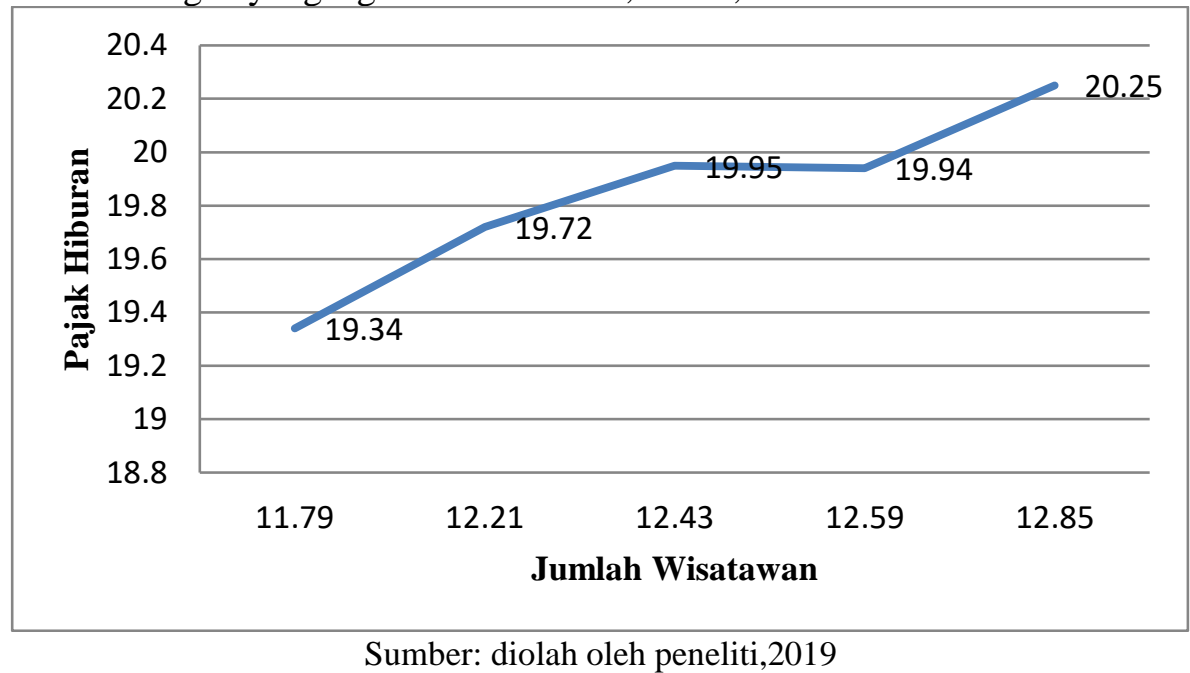

Gambar 4.3 Garis Linear Jumlah Wisatawan Dengan Pajak Hiburan 
Berdasarkan grafik linear pada gambar 4.3 korelasi antara jumlah wisatawan dengan penerimaan pajak hiburan bernilai positif berarti terjadi hubungan positif,artinya jika jumlah wisatawan meningkat maka penerimaan pajak hiburan akan meningkat dan sebaliknya jika jumlah wisatawan menurun maka penerimaan pajak hiburan akan menurun.

Tabel 4.4 Hasil Korelasi Jumlah Wisatawan Dengan Pajak Reklame

\begin{tabular}{|c|c|c|c|}
\hline \multicolumn{4}{|c|}{ Correlations } \\
\hline & & $\begin{array}{c}\text { Pajak } \\
\text { reklame }\end{array}$ & $\begin{array}{c}\text { Jumlah } \\
\text { wisatawan }\end{array}$ \\
\hline \multirow[t]{3}{*}{$\begin{array}{c}\text { Pajak } \\
\text { reklame }\end{array}$} & $\begin{array}{c}\text { Pearson } \\
\text { Correlation }\end{array}$ & 1 &,- 174 \\
\hline & Sig. (2-tailed) & & ,779 \\
\hline & $\mathrm{N}$ & 5 & 5 \\
\hline \multirow[t]{3}{*}{$\begin{array}{c}\text { Jumlah } \\
\text { wisatawan }\end{array}$} & $\begin{array}{c}\text { Pearson } \\
\text { Correlation }\end{array}$ &,- 174 & 1 \\
\hline & Sig. (2-tailed) & ,779 & \\
\hline & $\mathrm{N}$ & 5 & 5 \\
\hline
\end{tabular}

Sumber: diolah oleh peneliti,2019

Hubungan pajak reklame dan jumlah wisatawan berhubungan negatif sebesar $-0,17$ berarti keeratan hubungan pajak reklame dengan jumlah wisatawan hubungannya lemah berdasarkan hasil uji signifikan antara pajak reklame dan jumlah wisatawan memiliki hubungan yang tidak signifikan karena 0,77 >0,05. Jadi H0 diterima dan Ha di tolak.

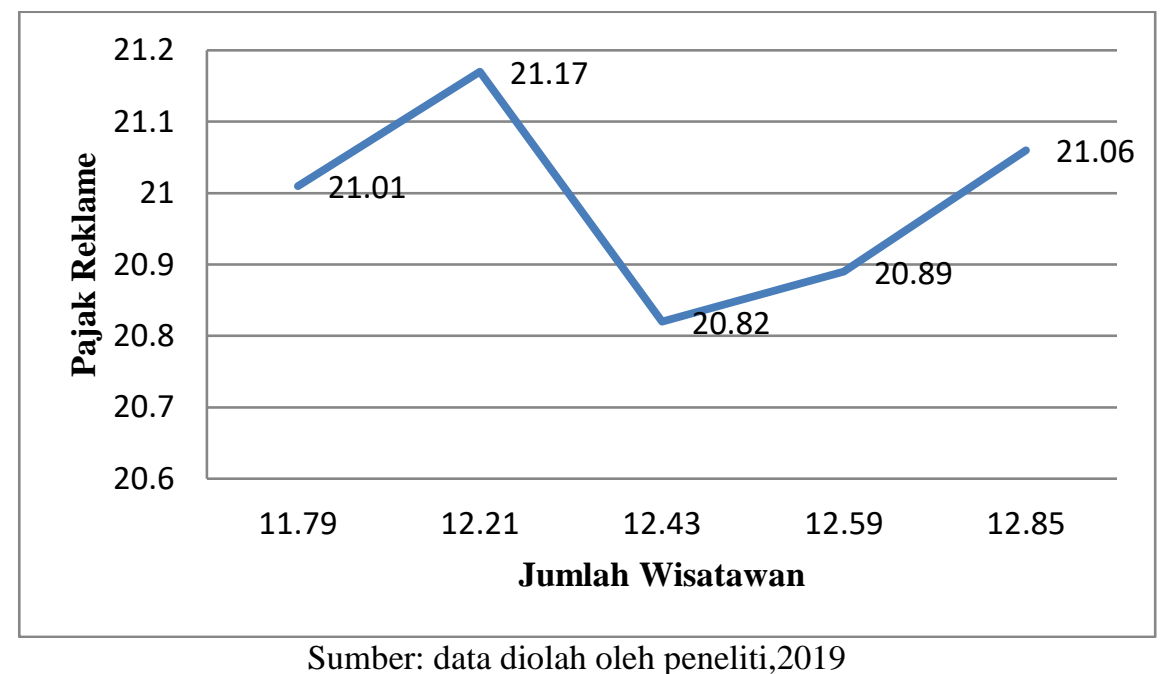

Gambar 4.4 Garis Linear Jumlah Wisatawan Dengan Pajak Reklame

Berdasarkan grafik linear pada gambar 4.4 korelasi antara jumlah wisatawan dengan penerimaan pajak reklame bernilai negatif berarti terjadi hubungan negatif, artinya jika jumlah wisatawan meningkat maka penerimaan pajak reklame akan menurun dan sebaliknya jika jumlah wisatawan menurun maka penerimaan pajak reklame akan meningkat.

Tabel 4.5 Hasil Korelasi Antara Jumlah Wisatawan Dengan Pajak Parkir Correlations

\begin{tabular}{l|c}
$\begin{array}{l}\text { Pajak } \\
\text { parkir }\end{array}$ & Jumlah \\
wisatawan
\end{tabular}




\begin{tabular}{ccc|c}
\hline Pajak Parkir & $\begin{array}{c}\text { Pearson } \\
\text { Correlation }\end{array}$ & 1 &, $927^{*}$ \\
\cline { 2 - 4 } & Sig. (2-tailed) & &, 024 \\
\cline { 2 - 4 } & $\mathrm{N}$ & 5 & 5 \\
\hline $\begin{array}{c}\text { Jumlah } \\
\text { wisatawan }\end{array}$ & $\begin{array}{c}\text { Pearson } \\
\text { Correlation }\end{array}$ &, $927^{*}$ & 1 \\
\cline { 2 - 4 } & Sig. (2-tailed) &, 024 & \\
\hline
\end{tabular}

Sumber: diolah oleh peneliti,2019

Hubungan pajak parkir dan jumlah wisatawan berhubungan positif sebesar 0,93 berarti keeratan hubungan pajak parkir dengan jumlah wisatawan hubungannya sangat kuat karena berdasarkan hasil uji signifikan antara pajak parkir dan jumlah wisatawan memiliki hubungan yang signifikan karena $0,024<0,05$. Jadi H0 di tolak dan Ha diterima.

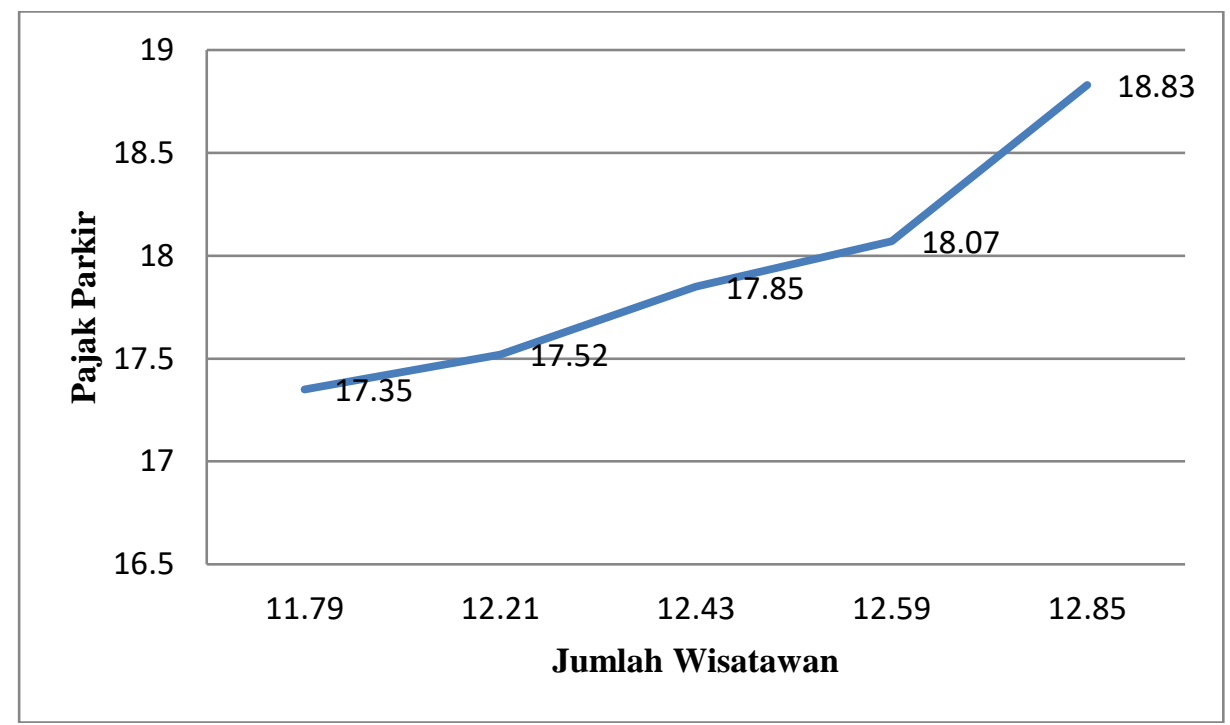

Sumber: diolah oleh peneliti,2019

\section{Gambar 4.5 Garis Linear Jumlah Wisatawan Dengan Pajak Parkir}

Berdasarkan grafik linear pada gambar 4.5 korelasi antara jumlah wisatawan dengan penerimaan pajak parkir bernilai positif berarti terjadi hubungan positif, artinya jika jumlah wisatawan meningkat maka penerimaan pajak parkir juga akan meningkat dan sebaliknya jika jumlah wisatawan menurun maka penerimaan pajak parkir akan menurun.

\section{Kesimpulan dan Saran}

\subsection{Kesimpulan}

1. Hubungan antara jumlah wisatawan dengan pajak hotel bernilai positif berarti terjadi hubungan positif, artinya jumlah wisatawan meningkat maka penerimaan pajak hotel akan meningkat dan sebaliknya jika jumlah wisatawan menurun maka penerimaan pajak hotel akan menurun.

2. Hubungan antara jumlah wisatawan dengan pajak restoran bernilai positif berarti terjadi hubungan positif, artinya jumlah wisatawan meningkat maka penerimaan pajak restoran akan meningkat dan sebaliknya jika jumlah wisatawan menurun maka penerimaan pajak restoran akan menurun.

3. Hubungan antara jumlah wisatawan dengan pajak hiburan bernilai positif berarti terjadi hubungan positif, artinya jumlah wisatawan meningkat maka penerimaan pajak hiburan akan meningkat dan sebaliknya jika jumlah wisatawan menurun maka penerimaan pajak hiburan akan menurun.

4. Hubungan antara jumlah wisatawan dengan pajak reklame bernilai negatif berarti terjadi hubungan negatif, artinya jumlah wisatawan meningkat maka penerimaan 
pajak reklame akan menurun dan sebaliknya jika jumlah wisatawan menurun maka penerimaan pajak reklame akan meningkat.

5. Hubungan antara jumlah wisatawan dengan pajak parkir bernilai positif berarti terjadi hubungan positif, artinya jumlah wisatawan meningkat maka penerimaan pajak parkir akan meningkat dan sebaliknya jika jumlah wisatawan menurun maka penerimaan pajak parkir akan menurun.

\subsection{Saran}
Berdasarkan simpulan yang telah diuraikan maka dapat diajukan saran yaitu peningkatan program-program yang berkaitan dengan promosi pariwisata, memperbaharui mekanisme pemungutan pajak serta meningkatkan jumlah objek pajak dengan menambah jumlah tempat hiburan yang akan menyumbangkan pajak hiburan untuk meningkatkan Pendapatan Asli Daerah (PAD) . Pemerintah Kabupaten Belitung diharapkan dapat memaksimalkan potensi pariwisata yang dimiliki sehingga dapat dijadikan sumber pendapatan daerah dan kesejahteraan masyarakat.

penulis ingin menyampaikan terimakasih kepada :

1. Ibu Dr. Hj. Devi Valeriani, S.E., M.Si selaku ketua program Studi Ekonomi Universitas Bangka Belitung.

2. Ibu Wiwih Widaningsih, S.Sn selaku pembimbing II yang telah bersedia membantu dan membimbing pada kegiatan kuliah kerja praktek di kantor Dinas Pariwisata Kabupaten Belitung.

3. Kepada pihak di Dinas Pariwisata Kabupaten Belitung yang telah berkenan memberikan izin utuk melakukan kuliah kerja praktek.

4. Kepada orang tua saya bapak Nazaruddin dan ibu Royana yang selalu mendukung, mendoakan dan memberikan motivasi dengan sepenuh hati.

5. Kepada seluruh teman-teman 17IE1 khususnya rekan magang saya di dinas pariwisata kabupaten Belitung Elvira Nadyatiana dan Husril.

\section{REFERENSI}

Mulyadi Aj.2012. Kepariwisataan dan Perjalanan. Jakarta: Raja Grafindo.

Peraturan Daerah Kota Depok. 2002. Pajak Hotel, Pajak Hiburan, Pajak Reklame, Pajak Restoran, dan Pajak Parkir.

Peraturan Daerah Nomor 11 Tahun 2011 Tentang Pajak Hiburan.

Priyatno D.2016. Belajar Alat Analisis Data dan Cara Pengolahannya dengan Spss Praktis dan Mudah Dipahami untuk Tingkat Pemula dan Menengah. Yogyakarta: Gava Media.

Pujiastuti Le dan Tahwin M.2016.Pengaruh Pajak Hotel, Pajak Restoran, Pajak Hiburan, Pajak Reklame, Pajak Penerangan Jalan, Pajak Parkir, Pajak Galian C dan Pajak Sarang Burung Terhadap Pendapatan Asli Daerah. Jurnal Jab.4(2).

Sekaran U dan Bougie R.2017. Metode Penelitian Untuk Basis Pendekatan PengembanganKeahlian.Jakarta. Salemba Empat.

Suandy E. 2010. Hukum Pajak Edisi 3. Jakarta : Salemba Empat.

Sugiyono.2014. Metode Penelitian Kuantitatif Kualitatif . Bandung: Alfabeta

Supriyanto. Pengaruh Jumlah Wisatawan Terhadap Penerimaan Pajak Hotel Melalui Tingkatan PDRB di Kota Makassar. Jurnal Berkalah Ilmiah Efisiensi.15(3).73-74.

Susyanti J dan Dahlan A. 2015. Perpajakan Untuk Praktisi Dan Akademisi. Malang:

Empatdua Media.

Wijaya I dan Sudiana Ik. Pengaruh Jumlah Kunjungan Wisatawan, Penerimaan Pajak Hotel, Restoran dan Pendapatan Retribusi Objek Wisata Terhadap Pendapatan Asli Daerah di Kabupaten Bangli Periode 2009-2015.E-Jurnal Ep Unud.5(12).1385-1386.

Yoga Dharma GAI dan Wenagama WI. Pengaruh Jumlah Kunjungan dan Pengeluaran Wisatawan Mancanegara Terhadap Produk Domestik Regional Bruto(Pdrb) Provinsi Bali Tahun 19962012. E-Jurnal Ep Unud. 4(2). 51-108. 